\title{
Berényi Esżter
}

Pannon Egyetem, MFTK Filozófia, Történettudomány és Antropológia Intézet

\section{Az autonómiától a szelekcióig}

\section{A közpolitika mint a szociológia tárgya}

\author{
A szabad iskolaválasztással kezdó oktatásszociológusként kerültem \\ kapcsolatba, egy olyan kutatás keretei között, amelynek nem \\ elsósorban az iskolaválasztás, hanem a helyi oktatásirányitás, az \\ egyenlótlenségek kezelése és az iskolák egymás közötti viszonya volt a \\ témája. Hamar kiderült azonban, hogy a szabad iskolaválasztás \\ megkerülhetetlen eleme ennek a témakörnek.
}

M indez - mint ahogy arról később bőven szó lesz - egyébként akkoriban valahogyan „,benne volt a levegőben”, legalábbis az oktatáskutatás levegőjében: ellentétben a 20. század utolsó évtizedével, a kritikai oktatáskutatók (szociológusok, közgazdászok egyaránt) figyelme tíz évvel később, az ezredfordulón, egyre inkább a szabad iskolaválasztás felé fordult. Felmerül a kérdés, hogy mennyiben tekinthető klaszszikus oktatásszociológiának ez a téma, hiszen valójában az, hogy egy oktatási rendszerben a tanulók intézmények közötti eloszlása milyen elveken alapul, oktatáspolitikai kérdés. Magyarországon jelentős hagyománya van az oktatáspolitika-kutatásnak, s az ezt müvelők sokszor rendelkeznek valamiféle szociológiai perspektívával az oktatáspolitikáról, de az azért nem mondható el, hogy az oktatáspolitika az oktatásszociológusok kedvelt területe lenne; mint ahogyan általában a közpolitika sem tartozik a szociológia kiemelt témái közé. Akár az az oka ennek, hogy a „közpolitikai elemzés” a szociológiai perspektívából túlságosan hatékonyság-elvünek tünik, akár az, hogy gyakorlatiassága miatt a közpolitikai elemzés nem felel meg mindenben a klasszikus tudományosság kritériumainak, mindenesetre a szociológia főáramában a közpolitikai folyamatok tanulmányozása nem tölt be kiemelkedő szerepet. Ugyanakkor a „mainstream” szociológiában mára elfogadottá vált, hogy a szociológiai kutatásnak választ kell tudnia adni aktuális társadalmi problémákra, ezért legtöbbször kutatási célként a gyakorlatban (azaz a forrásokért vívott ádáz küzdelemben) nem mindig elégséges a társadalmi mechanizmusok megértését kitüzni, hanem reflektálni kell a felmerülő problémák orvosolhatóságára vonatkozó társadalompolitikai igényekre is. Mindez a szociológia társadalmi hasznosságának bizonyítását is szolgálja. Ez persze akár önmagában is fontos cél lehetne a kutató számára, de mindenképpen ebbe az irányba igyekeznek terelni a szociológiai gondolkodást a különböző pénzosztó mechanizmusok is, amelyek sokszor még az elméleti irányú kutatások esetében is megkövetelik a hasznosulás előzetes megfogalmazását. A szociológusok többsége könnyen kerülhet olyan helyzetbe, hogy eredeti szándékaitól függetlenül közpolitikai ajánlást kell megfogalmaznia akkor, amikor a szélesebb közönség elé lépve kell beszámolnia tudományos kutatási eredményeiről. A szociológiától a közélet is elvárja, hogy képes legyen közpolitikailag releváns tudások előállítására. Egyes szociológusok örömmel alkalmazkodnak ezekhez az elvárásokhoz, mások pusztán legitimációs eszközként tekintenek rájuk, de mindannyian találkoznak a közpolitikai relevancia kérdésével. 
Valójában mind a szociológia, mind a közpolitika-alkotás fontos feladatának tekinti, hogy társadalmi problémákra mutasson rá, és ezek kezeléséhez járuljon hozzá; ez elég erős köteléket teremt a két terület között.

Közpolitika és szociológia viszonyáról a kanadai szociológus, Daniel Béland egy, az Amerikai Szociológiai Társaság részére írt jegyzetében egészen egyszerűen így fogalmaz: „mivel a köz problémáinak társadalmi konstrukciója mind a közpolitikai, mind a szociológiai viták egyik fontos része, ezért a szociológia szükségképpen foglalkozik közpolitikai ügyekkel" (Béland, 2009).

Ugyanakkor a szociológia és a közpolitika-alkotás nézőpontjai, a problémák konstrukciójának és a kezelésének módjai nem is térhetnének el jobban - ez pedig számos konfliktus forrása. Talán éppen ez a kettősség teszi egyszerre bonyolulttá, ugyanakkor kifejezetten érdekessé a két terület és a két területen dolgozók viszonyát.

A kozpolitikak direkt vagy indirekt tanulmanyozasa valójában nem idegen a klasszikus szociologiatol: Beland nem masra,mint Emile Durkheimre is hivatkozik, amikor is hangsulyozza, hogy Durkheim oktatasszociologiajanak fontos darabja a francia oktatasi reform tanulmanyozasa (Beland, 2009).

Talán nem véletlen a durkheimi utalás: hiszen különösen igaznak tünik a fenti állítás az olyan, nagy állami struktúrákat tanulmányozó szakszociológiákra, mint például az oktatásszociológia. Miközben sok oktatásszociológiai müben maga az oktatáspolitika kifejezés explicit módon nem jelenik meg, valójában ezen müvek legtöbbje fontos oktatáspolitikai relevanciával rendelkezik. Az oktatásszociológia olyan intézményekkel és szereplőkkel foglalkozik, amelyek nem tekinthetők a szó filozófiai értelmében autonómnak. Persze kérdés, hogy van-e ilyen autonómia egyáltalán; ezt feszegeti Marschall az „autonóm választó” kifejezést boncolgatva az oktatási reformok és az iskolaválasztás kapcsán (Marschall, 1996). Az autonómia korlátozott, olyan értelemben legalábbis mindenképpen, hogy a fenti szereplök és intézmények nem légüres térben léteznek. Intézményileg rögzített pozíciók, elvárt kimenetek, követelmények által szabályozott keretek között fejtik ki hatásukat. A fenti szabályok márpedig általában valamilyen közpolitikai szabályozás részei, vagy egy közpolitikai folyamat részeként jöttek létre.

Pierre Bourdieu, akinek iskolaszociológiája a mai napig fontos kiindulópont a kritikai oktatásszociológusok számára, is relatív (és látszólagos!) autonómiáról beszél az oktatási intézményekkel kapcsolatban, s müveiből egyértelmüen az olvasható ki, hogy a politikai-társadalmi kontextus erős hatással van arra, hogy miként veszi ki részét a társadalmi egyenlőtlenségek újratermelésében az iskola. Michael Apple az oktatásszociológia és az oktatáspolitika viszonyát boncolgatva egyenesen úgy ír: „,valójában az, amit oktatásszociológiaként tartunk számon: konstrukció... határait olyan szereplők összetett „közpolitizáló” cselekményei alakítják, akiknek van kellő hatalmuk arra, hogy érvényt szerezzenek elképzeléseiknek és arra is, hogy meghatározzák: mi a szociológiai kutatás legitim tárgya, és mi nem az" (Apple, 1996, 125-144. o.).

A szakszociológiák müvelése során, még ha nem is kerül szóba a közpolitika, valójában igen sokszor befolyással van a tanulmányozott területre. A szociológusok számára a közpolitika nemegyszer: vakfolt. A társadalom összetett ok-okozati viszonyrendszerében persze nem könnyü az elemzéskor a valóság komplexitását teljes mértékben követni (csúnya szóval: leképezni), és sokszor éppen a közpolitika az, ami kimarad a szociológiai magyarázatokból, amikor egy-egy társadalmi jelenséget vizsgálunk. Pedig valójában könnyen belátható, hogy közpolitikai folyamatok alakítják azt az intézményrendszert, azokat a pozíciókat, amelyeket vizsgál a szociológia. A közpolitika megkönnyít, lehetővé tesz bizonyos eseményeket, helyzetbe hoz szereplöket, míg mások hangját elveszi, bizonyos pozíciókat leértékel; befolyással van nemcsak az intézményrendszer müködésére, de a cselekvő egyének stratégiáira is. Stephan Ball is arra figyelmeztet, hogy az oktatáskutatás sokszor mintha megfeledkezne az oktatáspolitikáról, s a 
tanárok, az iskolák kontextusuktól független tényezőknek tünnek fel az elemzésekben (Ball, 1997, 265. o.).

Még érdekesebb a helyzet, ha nem „,a szociológiára”, hanem „a szociológusokra” gondolunk, s az ő közpolitikához való viszonyukat firtatjuk. A szociológusok nagy része munkája során kapcsolatba kerül közpolitikákkal. Akár azért, mert nem hagyja figyelmen kívül az általam ,vakfoltnak” nevezett jelenséget, vagy mert valamiféle ,,alkalmazott” szociológiai kutatásra kap megbízást. Néha a szociológus akadémiai kutatásai során olyan „szakértővé” vált, akinek a véleményére ,adnak” a politikai résztvevők, s idézik, felhasználják a meglátásait, vagy kifejezetten felkérik javaslattételre. A ,szakértelem”, a „,szociológus mint szakértő” megjelenése és terjedése rokonítható ahhoz a jelenséghez, amelyet a közpolitika-elemző szakirodalom a 20-21. század fordulójára nézve a „szakértelem burjánzásának" (Maasen és Weingart, 2005) egyik aspektusaként írt le. A szociológus és a közpolitikai szakértő szerep kiegészítheti egymást, de szülhet szerepkonfliktust is. Agnes Van Zanten egy tanulmányában ebböl a szempontból tüzetesen elemzi Pierre Bourdieu viszonyát az oktatáspolitikához (Van Zanten, 2005).

Az előbb utaltam arra, hogy a közpolitika tanulmányozása nem tartozik a „mainstream" szociológia kedvelt területei közé. A szociológiának ugyanakkor létezik olyan felosztása, amely egyértelmüen kijelöli a közpolitika helyét a szociológiai tevékenységek sorában, tulajdonképpen elhelyezi a fő irányhoz képest. A 21. század elejének egy, a szociológiai önreflexiót illető fontos esszéjében Michael Burawoy négyféle szociológiát különböztet meg: professzionális szociológiát (ő ezt érzékeli „mainstream”-nek), kritikai szociológiát, valamint „közpolitikai” (policy sociology) és „köz”-szociológiát (public sociology) (Burawoy, 2006).

Burawoy cikkében elsősorban a „közszociológia” jelenségére reflektált, de négyes felosztásából világossá válik, hogy a közpolitikával foglalkozó szociológia szerves része annak, amit ő ,,szociológiai munkamegosztás”-nak nevez. Ebben a kategorizálási rendszerben a közpolitika szociológiája instrumentális típusú tudásként jelenik meg, amely egy-egy konkrét megrendelő érdekeit fogadja el szempontként. Burawoy felosztásában a közpolitikai szociológiában a tudás konkrét, az igazság pragmatikus, s az irányzat legitimitását a hatékonyság adja; a közpolitikai szociológia múvelője a megrendelőnek tartozik elszámolással, célja pedig a közpolitikai beavatkozások lehetővé tétele, javítása. Miközben élesen különválasztja a különböző típusú szociológiákat, Burawoy hangsúlyozza a közöttük lévő kapcsolódási pontokat is, s igyekszik rámutatni arra, hogy nem „élhetnek egymás nélkül”. Evidensnek tekintett módon, a szociológia mindhárom további alfajának szüksége van a professzionális szociológia által termelt tudásra; de példákat hoz arra is, hogy a „négyféle szociológiai munkamódszer” ideális esetben csak domináns elkötelezettségeket jelent, s valójában szükségszerü az átjárás közöttük. Hangsúlyozza például, hogy az általa meglehetősen instrumentálisnak, és a fennálló uralmi viszonyok legitimálásához hozzájárulónak leírt közpolitikai szociológia is átválthat „kritikaivá”.

Meggyőződésem, hogy a közpolitika szociológiai elemzése ennél jóval erősebben is kapcsolódhat az „egyéb” szociológiákhoz; például a közpolitikai szociológiának egyben közszociológiának is kellene lennie, hiszen a hétköznapokban érzékelhető jelenségekkel, a közpolitika által érintett személyekre befolyással lévő döntési folyamatokkal foglalkozik. Az egyszerü halandókat a klasszikus szociológiai elméletalkotás világánál jobban érdeklik azok a kérdések, mint például az iskolaválasztás kérdése is, amelyeket maguk is alkalmaznak, amelyekkel kapcsolatban tudatosan konkrét cselekvéseket hajtanak végre.

A közpolitikával foglalkozó szociológia kapcsolata a kritikai szociológiával is jóval szorosabb lehet, mint ahogyan azt Burawoy felvázolja. Vannak, nem is kevesen, akik magukra mint kritikai közpolitikai szociológiát müvelökre tekintenek. Ök sokat hivatkoznak Jenny Ozga definíciójára, aki szerint az általa (is) müvelt közpolitika-elemzésre jellemző, hogy „a szociológiai hagyományban vannak a gyökerei, történelmi kontex- 
tusban vizsgálja tárgyát és elsősorban kvalitatív és megvilágító erejü technikákkal él" (Ozga, 1987, 144. o.).

Nemcsak a kvalitatív technológiák használata, de a történelmi kontextus hangsúlyozása is arra figyelmeztet, hogy a „közpolitika szociológiája” itt jóval többet jelent, mint a Burawoy által leírt, hatékonyságelvü, alkalmazott szociológiai kutatási irány. És nagyon is úgy tünik, hogy a 21. század elején egyre-másra születtek olyan közpolitikákat szociológiai perspektívából vizsgáló művek, amelyekre jóval inkább volt jellemző, hogy „uralom”, „érdek”, „diskurzus”, „,egyenlőtlenség”, a „hogyan müködik” fogalmaival operáltak és ezek a kérdések érdekelték őket, semmint a Burawoy által hangsúlyozott hatékonysági, megvalósíthatósági szempontok.

Azt gondolom, hogy a kritikai szemlélet az, amely leginkább létjogosultságát adja a közpolitikák szociológiai elemzésének. Ez adja ugyanis biztosítékát annak, hogy a közpolitikák szociológiai elemzése meghaladja a merő instrumentalizmus által felvetett kérdéseket és ne pusztán ezekre keressen választ.

Áttekintő művében a közpolitikai elemzéseket több dimenzóban felosztó Dunn (Dunn, 1981) prospektív és retrospektív közpolitikai elemzéseket különböztet meg. A prospektív elemzések megelőzik a közpolitikai lépéseket; a szerző szerint ezeket főként közgazdászok, döntéskutatók, rendszerelemzők készítik.

A retrospektív elemzéseket ezzel szemben nem érdeklik a specifikus és befolyásolható közpolitikai célok, hanem a „közpolitikák” okait és következményeit írják le, s viszonylag általános problémákat vizsgálnak. Ezek az elemzések, írja Dunn, olyan információt szolgáltatnak, ami segít megérteni a problémát, de nem mutat rá arra a jól kézzelfogható közpolitikai változóra, amin változtatni érdemes a probléma megoldásának érdekében. Éppen ezért a retrospektívnek nevezett elemzések ritkán mutatnak fel olyan eredményeket, amelyek közvetlenül felhasználhatók lennének a döntéshozók számára. Nem meglepő tehát, hogy a döntéshozók közvetlen szempontjából a prospektív elemzés a hasznos; ugyanakkor hosszútávon legalább ugyanilyen fontosak a retrospektív elemzések, hiszen ezek tudnak tényleges információkat nyújtani egy közpolitikai folyamat átfogóbb eredményeiröl, és képesek lehetnek új fogalmi kereteket ajánlani a policy-folyamatok megértéséhez.

A „közpolitika szociológiája” a fentiekben leírtak alapján nyilvánvalóan a retrospektív elemzések kategóriájába esik, s a hatékonysági, stabilitási szempontok helyett alapvető értékek közötti választásokként, kommunikatív aktusként, problémakonstrukcióként és már-már véget nem érő folyamatként tekint a közpolitikákra. Ám ez a komplex valóságértelmezése valóban nehézkessé teszi az egyszerü kérdésekre adható egyszerü válaszokhoz való viszonyát.

Kicsit olyasmi ez, mint amikor a klasszikus viccben egy részeg ember éjszaka körbe-körbe jár egy lámpa körül, s amikor egy járókelő megkérdezi, hogy mégis mit csinál, elmondja, hogy elvesztette a lakáskulcsát, és azt keresi. A járókelő megkérdezi, hogy itt vesztette-e el, a részeg erre azt válaszolja, hogy nem, hanem még valószínüleg öt buszmegállóval korábban valahol. Erre érkezik az adekvát kérdés: „akkor miért itt keresi?”, s a még adekvátabb válasz: „Mert csak itt van világos.”

A viccben leírt helyzet voltaképpen nagyon pesszimista, hiszen végső konklúziója az, hogy a lakáskulcsot semmiképpen sem lehet megtalálni. Ha világosban keresi az ember, akkor azért, mert nem jó helyen; ha visszamenne a jó helyre (amiröl nem lehet pontosan tudni, hogy hol van), akkor azért nem találná, mert sötét van.

A társadalmi valóság komplexitásával is valami hasonló a helyzet. El kell fogadnunk, hogy a megismerés teljessége esélytelen. Megtehetjük, hogy redukáljuk a komplexitást; ekkor bevezethetünk olyan eszközöket, amelyek hasonlítanak az utcai lámpára: legalább megvilágítanak bizonyos részleteket, leegyszerüsítik a komplexitásában megoldhatatlannak látszó feladatot; vagy sötétben tapogatózva elindulhatunk valahova, amiről nem 
tudjuk, hogy hol van, de tudjuk, hogy ahol most vagyunk, ott nincs az, amit pontosan keresünk. Mindkét esetben találkozhatunk nagyon érdekes dolgokkal, amelyek közelebb vihetnek a célunkhoz, és (sok minden egyéb mellett) a valóság komplexitásáról alkotott elképzelésünk is befolyásolja, hogy melyik megoldást választjuk.

A kritikai közpolitika-kutatás a komplexitást hangsúlyozza. Stephen Ball a közpolitika szociológiájával kapcsolatban felhívja a figyelmet az éles ellentétre a között a szemlélet között, amely „a közpolitikákat tisztának, absztraktnak és stabilnak tekinti, és aközött, amely szerint a közpolitikák így-úgy összerakottak, befejezetlenek, nem koherensek és instabilak" (Ball, 1997, 265. o.). A befejezetlenségnek, instabilitásnak ez a belátása közelebb visz ugyan a valóság megragadásához, de távolít attól, hogy egyszerü és felhasználóbarát válaszok szülessenek egy mégoly türelmes és érdeklődő, ámde határidők és költségvetési zárószavazások által sürgetett döntéshozó számára.

A döntéshozók számára praktikus haszonnal kecsegtet például a közpolitika ciklikus felfogása. A ciklikus szemlélet a közpolitika kialakulásának különböző szakaszait különbözteti meg egymástól. Ebben a megközelítésben a közpolitika-alkotást hagyományosan egy olyan ciklikus történésként szokás ábrázolni, amely az alábbi öt szakaszból áll: 1 . problémadefinícó; 2. közpolitikai napirend (agenda) kidolgozása 3. törvényalkotás, szabályozás; 4. implementáció; 5. reflexió, értékelés. A közpolitika szociológiai jellegü kutatásai során ugyanakkor ez a ciklikusság sehogyan sem akarja megmutatni magát; a kutató, ha tényleges mechanizmusokkal kíván foglalkozni, ritkán bukkan nyomára éles határoknak a ciklusok között, nehéz nem észrevennie, hogy a ciklusok sorrendje sokszor esetleges, hangsúlyaik eltolódnak; a fontos történések néha valahol a „cikluson kívül” történnek.

A hagyományos ciklikus elképzelésben fontos szerepet kap a „problémadefiníció”. Ugyanakkor hiba volna a közpolitikákra kizárólag mint problémák megoldására létrejövő erőfeszítésekre tekinteni. A közpolitikák szerepe nem pusztán a problémák „,megoldása". Nemcsak azért, mert a közpolitika a hétköznapi valóságban legalább annyira generál bizonyos problémákat az érintett szereplők számára, mint amennyire megold másokat; hanem azért is, mert legalább ilyen fontos tulajdonságuk a közpolitikáknak, hogy átalakítják és megalkotják azokat a jelentési mezőket, amelyeken belül az aktorok problémákat észlelnek, és (re)definiálják problémáikat, és kipróbálják az általuk favorizált megoldásokat. Tehát ,„a közpolitika-alkotás nem a probléma megoldása, hanem a problémák új reprezentációjának konstruálása, amely létrehozza ezen problémák kezelésének társadalmi-politikai feltételeit, és ekképpen strukturálja az állam cselekvését" (Muller és Surel, 1998, 31. o.). A közpolitikák problémamegoldás helyett inkább ,jelentést adnak a világnak", abban az értelemben, hogy ez a társas konstrukciós folyamat mindig kombinálja a kezelendő problémáról való elgondolást a közpolitika által segített társadalmi csoport képéről és a társadalmi változásról alkotott elgondolással.

Kifejezetten a probléma-központúság elleni érvként jelent meg a ciklikus elképzelésben a „,napirend-kialakítás”-ként nevezett szakasszal kapcsolatban Kingdon „lehetőség-ablak" elmélete (Kingdon, 1984). Kingdon arra tett kísérletet, hogy megmagyarázza: hogy lehet, hogy bizonyos problémák kiváltanak közpolitikai válaszokat, míg mások nem. Meglátása szerint a közpolitikai napirendre kerülést leginkább úgy lehet magyarázni, ha három különböző, egymástól függetlenül létező áramlatot különböztetünk meg egymástól: a problémák áramlatát, a megoldások áramlatát és a politikai áramlatot. A problémamegoldó közpolitikai megközelítéssel ellentétben Kingdon szerint a „megoldások” nem azért születnek, hogy specifikus problémákat orvosoljanak velük, és nem is a problémák hívják elő őket. A fenti áramlatok egymástól függetlenül léteznek, de egy problémának (pl. munkanélküliség; oktatási mérési eredmények) csak akkor van esélye napirendre kerülni, ha létezik egy potenciálisan jó megoldás is a probléma kezelésére, és a politikai szabályok és a politikai élet jellegzetességei egymásra vetülnek, tehát, ha a három áramlat egy adott 
ponton találkozik, s ekképpen megnyit egy „lehetôségablakot” (window of opportunity). Ezek a lehetöségablakok Kingdon szerint viszonylag rövid ideig vannak nyitva.

A közpolitikai szociológiai megközelítés a közpolitika-alkotásra mint társadalmi folyamatra tekint, azaz abból indul ki, hogy a közpolitika-alkotásra hatással van az a társadalmi kontextus, amelyben létrejön, valamint hogy a közpolitika-alkotás megértése során nem tekinthetünk el attól a fontos ténytöl, hogy a közpolitikák fontos aktorok interperszonális kapcsolataiban, alkuk és kompromisszumok keretében jönnek létre és formálódnak.

A kormányzás és a közpolitika-alkotás szakirodalma az elmúlt évtizedekben hangsúlyozza, hogy a 20. század végére megváltozott az a kontextus, amelyben a kormányzás zajlik. A komplex társadalmi-gazdasági viszonyrendszerek miatt a modern demokratikus államok és kormányaik már nem olyan központi szereplők, akik egymagukban képesek lennének akaratukat megvalósítani, sok másik szereplő érdekével kell számolniuk a komplex döntési folyamatok során.

A ciklikus felfogáshoz képest Stephan Ball például „közpolitikák” helyett „,közpolitikai pályaívekként" (policy trajectory) igyekszik elképzelni a kutatás tárgyait. Ball szavaival: ,a közpolitikai pályaívekben gondolkodó perspektívát a közpolitika dinamikája érdekli... Ez a perspektíva a közpolitikák fejlődési, változási és hanyatlási módjait, valamint inkoherenciáit vizsgálja időben és térben. Itt a közpolitika-alkotás olyan folyamat, amely a jelentésért folytatott küzdelmek terepén zajlik; diskurzuspolitika" (Ball, 1997, 266. o.).

Ball hangsúlyozza, hogy a közpolitikák lehatárolatlanok. „Amikor egy »közpolitikára« fókuszálunk, készségesen elfelejtjük, hogy közben léteznek egyéb közpolitikák is, s egyik létrejötte ösztönözheti vagy éppenséggel gátolhatja egy másik létrejöttét vagy megvalósulását" (Ball, 1997, 267. o., saját fordítás).

Az elsősorban a frankofón területen elterjedt közcselekvés (action publique; Comaille, 2004) koncepciója pedig azt hangsúlyozza, hogy a központi döntéshozó szerveken kívül nagyon sokféle aktornak van jelentős szerepe a közpolitika kialakulásában, és hogy attól a társadalmi kontextustól sem szabad eltekinteni, amelyben a közpolitikát létre kívánják hozni, és amely alapvetően befolyásolja a közpolitikai lehetőségek tárházát.

A közpolitika-alkotás hosszas és bonyolult folyamat tehát, és a fenti elméletek amellett érvelnek, hogy a közpolitikát nem érthetjük meg, és nem modellezhetjük helyesen, ha pusztán a döntés megszületésének pillanatát és a vonatkozó törvényi normát tartjuk szemünk elött. Csak leszükített értelmezést tesz lehetővé, hogyha a döntéshozatali folyamatot felülről lefelé irányuló, lineáris szabályozási láncolatként vizsgáljuk (erről bővebben lásd Delvaux és Mangez, 2008). A közcselekvés szociológiája a közpolitikát időnként lényeges váltásokkal - paradigmaváltásokkal - tarkított, mégis alapvetően apró változások nyomán alakuló folyamatként tekinti, amelynek megértése nem lehetséges a közpolitika-alkotás társadalmi kontextusának figyelembevétele nélkül. A közcselekvési megközelítésben fogantak azok az elképzelések, amelyek egyenesen amellett érvelnek, hogy a közpolitikák már csak azért sem szakaszolhatók, mert voltaképpen sohasem beszélhetünk végleges közpolitikáról: azok mindig lezáratlanok, és állandó változásban vannak, hiszen a „lezárási szakaszban” voltaképpen kiigazítás, új program megalapozása történik.

Ugyanakkor a közpolitika ciklikusságának elképzelésén alapuló közpolitikai elemzést olyan kritikák is érik, amelyek ezt a fajta elemzést túlzottan instrumentálisnak, a közpolitika diszkurzív jelentőségét figyelmen kívül hagyónak érzik. Rosen (2009) például arra hívja fel a figyelmet, hogy a közpolitikák instrumentális szemlélete mellett inkább a közpolitikák szimbolikus jelentőségére kell koncentrálni, mivel a közpolitikákkal a döntéshozóknak sokszor nem is az az elsődleges céljuk, hogy megoldjanak egy adott problémát, hanem az, hogy átformálják a probléma társadalmi reprezentációját, azaz megváltoztassák a problémával kapcsolatos beszédmódot és közhangulatot. 


\section{A szociológia mint közpolitikai elemzés: vizsgálati dimenziók ${ }^{1}$}

A továbbiakban azokat a fontos szempontokat, területeket, szinteket fogom áttekinteni, amelyek szükségesek a közpolitikák társadalomtudományos vizsgálatához.

\section{Közpolitika és irányítás}

Noha a jogszabályalkotást a közpolitika szociológiája is lényegesnek tekinti, a szabályozás hagyományosan elemzett módjai mellett figyelembe veszi ugyanakkor az egyéb szabályozási eljárásmódokat, amelyek egyszerre több irányból (külső irányítás és önszabályozás), különböző kormányzási szintek találkozásában (nemzetközi, nemzetek feletti, nemzeti, regionális, kistérségi, helyi) és különböző szektorokat összekötve (kormányzati, félkormányzati, önkormányzati és nem-kormányzati) fejtik ki hatásukat.

A hagyományos ciklikus megközelítésben a közpolitika-alkotás fontos színtere az államigazgatás: a különböző törvényhozó, igazgatási testületekben zajlanak a ciklus „szakaszai”. A szakaszolhatósági elképzelés könnyen beleilleszthető a klasszikus, még Max Weber által felvázolt bürokratikus igazgatási rend ideáltipikus modelljébe. A közpolitika szociológiai megközelítése azonban fenntartásokkal kezeli a klasszikus bürokráciaelméletet, s jóval inkább igaz rá, hogy a bürokráciakritikák köpönyegéből bújt elő. Amennyiben ugyanis a közpolitikák vizsgálatakor nem esünk abba a hibába, hogy kizárólag a formálisan rögzített eljárásokat vizsgáljuk, akkor gyakran nem találkozunk sem az aktaszerüség, sem a racionalitás, sem a szabályozottság jeleivel. Éppen ellenkezőleg: lépten-nyomon bürokratikus diszfunkciókba, a formális és informális erőviszonyok és a legkülönfélébb érdekek között megnyilvánuló harcokba ütközünk.

De nemcsak a szervezetszociológusok számára közhelynek számító bürokráciakritikák ismerete gondolkodtat el arról, hogy egy-egy közpolitikai történéssorozat vizsgálatakor mennyire szabad kizárólag a bürokratikus igazgatás ügymenetére és ennek írásos/formális nyomaira (törvényi szöveghelyek, rendeletek) hagyatkozni a vizsgálatkor.

A szakpolitika-alkotás irányítási eszköztárában végbemenő egyik igen jelentős változás az volt az elmúlt néhány évtizedben, hogy a hagyományos bürokratikus eljárási formák továbbélése mellett más logikán nyugvó, újszerü irányítási módok és formák jelentek meg, s ezek egyre nagyobb befolyást nyertek a közpolitikai térben. Sokszor éppen a bürokratikus eszközök kudarcai után fedezték fel a döntéshozók és tanácsadóik maguknak ezeket a reményt keltő eszközöket, amelyek a közvetettebb, ám hatékonyabb irányítás lehetőségével kecsegtetnek. Az új eszközök közül jó néhány eredetileg a nemzetek feletti közpolitikai térben (pl. OECD, EU, Világbank stb.) született meg, s elsösorban arra hivatottak, hogy az egy-egy közpolitikai területről előállított tudástermelés révén ösztönözzék a nemzeti kormányokat, hogy a nemzetközileg vagy a nemzetek feletti szervek által elvárt normákhoz igazítsák müködésüket. Ezekkel a közvetett eszközökkel kapcsolatban a közpolitikai elemző szakirodalom ,puha” kormányzási eszközökröl beszél (pl. Grek és mtsai, 2009), hiszen alapvetően nem kötelező érvényü elöírások formájában, hanem diskurzusalakító erejüknek köszönhetően tesznek jelentőségre szert a nemzeti oktatáspolitikai térben. A nemzetek feletti szervek ,„puha” eszközei mellett a nemzeti oktatáspolitikai térre is egyre inkább jellemző, hogy az elérni kívánt célokat sokszor közvetett módokon, különbözö, nem jogszabályi eredetű szabályozóeszközök (pályázatok, benchmarkok, indikátorok, jó gyakorlatok terjesztése stb.) felhasználásával igyekeznek kikényszeríteni, ezért ezeket (egyéb jellegzetességeiktől függően) neo- vagy posztbürokratikus irányítási eszközöknek nevezzük (Maroy, 2007). Persze itt érdemes megjegyezni, hogy az „új” eszközök megjelenéséről beszélve nem gondolhatjuk, hogy ilyen típusú irányítási eszközök ne léteztek volna a modern államigazgatás megjelenését 
megelőzően is. Hiszen Michel Foucault például a modern állam genealógiájának vizsgálatában a 18. századdal kapcsolatban beszél a „kormányzás taktikájának” (Foucault, 1998, 113. o.) megjelenéséről, azaz arról, hogy megjelenik az a gondolat, hogy nem a törvény útján, hanem praktikus taktikák révén - azaz különböző közvetett eszközökkel lehetséges a leginkább a kormányzás.

A neobürokratikus törekvések összefoglaló jellemzésére alkalmas az „új közmenedzsment" ('New Public Management', NPM) fogalma. AZ NPM eljárásait a politikai aktorok a vállalati irányítás eszköztárából (pl. indikátor, jó gyakorlat, protokoll, benchmarking) kölcsönzik, a hatékonyság maximalizálására törekvő piaci szemléletű irányítási elveket egyre szélesebb körben alkalmazzák a közszektorban (Hood, 1991). Az új közmenedzsmentben a hagyományos bürokratikus irányítási szemlélet találkozik a hatékonyságra való törekvéssel. A neobürokratikus eljárások jellemzője, hogy ellentétben a hagyományos, elsősorban törvénykezésalapú szabályozási eljárásokkal, az elérni kívánt célokat nem vagy nem pusztán jogszabályok útján, hanem sokszor közvetett módokon, különböző, nem-jogszabályi eredetü szabályozó eszközök (pályázatok, benchmarkok, jó gyakorlatok terjesztése, stb.) beiktatásával kényszeríti ki. Mindez jellemzi a neo-bürokratikusságtól megkülönböztetendő posztbürokratikusságot is, ebben a szemléletben ugyanakkor az ellenőrzés, a kikényszeríthetőség szem előtt tartása mellett fontos szerepet kap a koordináció, a kooperáció és a hálózatosság is.

A bürokratikus szabályozás esetében a szabályozó erö a hierarchiában betöltött pozícióhoz köthető. Az eljárások standardizáltak, írott szabályok rögzítik őket, ami gyakran vezet rutineljárások kialakulásához, a hangsúly a külső és a közvetlen ellenőrzésen van. A posztbürokratikus szabályozás esetében, mivel a legtöbb feladat és tevékenység erösen tagolt, döntő szerepe van a koordinációnak; az irányítást nem egy külső ellenőrző szerv kényszeríti ki, az ellenőrzési feladatokat delegálják, a bizalom és a személyes elkötelezettség kulcsszerepet kap. A posztbürokratikus szabályozásban az információ és a tudás szerepe felértékelődik a közpolitikai folyamat során. A posztbürokratikus oktatásirányításra szolgáltat példát a kvázi-piacok (szabad iskolaválasztás) és az értékelő állam (mérés-értékelés, elszámoltathatóság) egyre erösödő szerepe az oktatásban.

Christian Maroy fogalmazta meg azt a hipotézist, amely a bürokratikus és a posztbürokratikus szabályozás közti elmozdulással foglalkozik: eszerint a szakpolitikai folyamatokban egyre jellemzőbb tendencia a posztbürokratikus szabályozási eljárások megjelenése (Maroy, 2007).

A szakirodalom a posztbürokratikus szabályozóeszközöknek legjelentősebb típusaként tekint az úgynevezett információs típusú szabályozóeszközökre. Ezek új tudásformák termelése, bevezetése és elterjesztése révén járulnak hozzá a közpolitikai szabályozáshoz. Abban a meggyőződésben, hogy a mérés, az információszerzés javítja a kormányzás hatékonyságát, a döntéshozók egyre részletesebben informálódnak a közpolitikai területek különböző aspektusairól. A posztbürokratikus szabályozásban az információ és a tudás maga is szabályozó tényezővé válik: a mérési, értékelési eredmények például a közpolitika érintettjeit informálják saját müködésükről, lehetővé teszik a mások müködésével való összehasonlítást, és arra is hivatottak, hogy elösegítsék a müködés megváltoztatását (hatékonyabbá tételét) is.

A továbbiakban a tudást mint a közpolitikai szabályozás egyre inkább felértékelődő eszközét tanulmányozom részletesen. 


\section{Tudás és (köz)politika}

A tudás mint társadalomigazgatási tényező szerepe fokozatosan értékelődött fel az elmúlt évtizedek során. A modern társadalmak kialakulását vizsgáló müvében Wagner (1994) hivatkozik arra a szociológia által jól ismert jelenségre, hogy a társadalmi bizalom vagy a társadalmi biztonság hagyományos formái felbomlottak a modernizációs folyamatok hatására. Wagner szerint ebben a modernizációs folyamatban a társadalomtudományok segítségével az objektivitásra törekvő tudás vált a hagyományos formák helyett olyan fontos osztályzási kritériummá, amelyen keresztül a modern individuum felügyelhető és szabályozható. A tudás azonban nem a természet lágy ölén terem, hanem társadalmi konstrukció. Kétféle elképzelés létezik arról, hogyan keletkezik és hogyan jelenik meg a közpolitika-alkotásban. Az első, „hagyományosabbnak” nevezhető elképzelés szerint, amelyet Gibbons és szerzőtársai (Gibbons és mtsai, 1994) 1. típusú tudástermelésnek neveznek, tudás és politika kapcsolata egyirányú: a hagyományos diszciplináris keretek között termelt tudást a politika - ha kívánja - felhasználja. Gibbons és szerzőtársai szerint tudás és politika fenti, lineárisnak elképzelt kapcsolata helyett a 20. század közepétől a közpolitika-alkotás valósága sokkal inkább a 2-es típusúnak nevezett tudástermelési modellel ragadható meg. Eszerint a tudástermelés jellemzően interdiszciplináris, problémaorientált és kontextusfüggő, vagyis a politikával kölcsönös függésben jön létre, reagálva arra a politikai elvárásra, hogy a kutatás politikailag releváns témákat feldolgozva, könnyen alkalmazható tudást, tudásokat állítson elö.

Érdemes különbséget tenni a különböző típusú tudások között is. Megkülönböztetünk tudományos, laikus (a közpolitika érintettjeinek tudása), hallgatólagos (nem verbalizált, gyakorlatban szerzett és továbbadott tudás esetünkben pl. az államigazgatás müködéséről) és gyakorlati (pl. a döntéshozó terepismerete) tudásokat. Egy-egy közpolitika esetén mindezen tudásokat és tudások hordozóit érdemes figyelembe vennünk.

A tudás nem függetleníthető létrejöttének körülményeitől: a tudás sem objektív és hatalommentes. Ellenkezőleg, aszimmetrikus hatalmi viszonyok közepette jön létre, érdekektől vezérelt, társadalmilag beágyazott, és egyenlőtlenségektől terhelt.

A tudás nem is állandó. A személyközi interakciók egyik közegből a másikba történő áramlása során más és más formában, más és más jelentésárnyalattal jelenik meg. A tartalom a közvetítés folyamán szükségképpen módosul, vagy legalábbis más és más aspektusai válnak hangsúlyossá.

A tudásra mint a kormányzás fontos eszközére irányuló elképzelések nem új keletüek, s nem is állítják azt, hogy ez a jelenség csupán az elmúlt évtizedekben jelent meg a kormányzási eszköztárakban. Michel Foucault a statisztikák kormányzási szerepének elemzésekor például egészen a 17. századig megy vissza okfejtései során (Foucault, 1998). Max Weber pedig kifejezetten a tudást tartja a racionalizáció, az ő szóhasználata szerint „,a világ varázstalanítása” fontos eszközének. Ugyanakkor az a folyamat, amelynek során a tudás politikával kapcsolatos szerepe fokozatosan értékelődött fel, a 20. század második felében nemcsak eröteljesebbé, hanem a politikai diskurzusban is explicitté vált, és egyre hangsúlyosabb szerepet kapott.

Ezzel kapcsolatban érdemes felidéznünk Jürgen Habermas tézisét a modern kapitalista társadalmak legitimációs válságairól (Habermas, 1994). Habermas azon a véleményen van, hogy a modern kapitalista államokban a 20. század második felére felbomlottak azok az alapvető ideológiai összetartó erők és értékrendek, amelyek korábban biztosították a hatalom legitimitását az alattvalók/polgárok körében. Habermas azt állítja, hogy a legitimációs krízis ellensúlyozásaképpen több új jelenség született, ezek egyike a jóléti állam, ugyanakkor felhívja a figyelmet arra is, hogy a politikai élet egyre erőteljesebb és aprólékosabb szabályozása (ez tulajdonképpen a weberi bürokratikus legitimitáselmélet felfokozásaként is értékelhető) is ennek az újfajta legitimációs kényszernek köszönheti 
létét. Ha, követve Habermas gondolatmenetét, a világnézetek és az ideológiák immár nem szolgálnak kellő legitimitással a politika számára, akkor nyilvánvalóan fokozottan igaz ez a jelenség a szakpolitika-alkotásra nézve. Valószínüleg éppen ezzel a jelenséggel köthető össze az, hogy a tudás mint a szakpolitikákat legitimáló eszköztár ekkoriban válik a közpolitikai diskurzus hangsúlyos elemévé. A 20. század 70-es, 80-as éveiben Nyugat-Európában és az angolszász világban egyre inkább tapasztalható volt a „társadalom mérnökeibe vetett bizalom" gyengülése, s, elsőként az angolszász közpolitikai színtéren, megjelent az az igény, hogy a közpolitika-alkotás ne tervezésen, hanem azon alapuljon, hogy „mi múködik” (Davies HTO, Nutley SM, Smith PC, 2000). Ily módon alakult ki a „tényeken/bizonyítékokon alapuló közpolitika-alkotás” fogalma, amely egyértelmű módon demonstrálja a tudásra irányuló közpolitikai igényt, s amelyre az egyik legismertebb példa a „No Child Left Behind” amerikai programja, amely a tanulói eredményességet mérve, tehát az oktatási rendszer müködésének konkrét, számszerüsíthető bizonyítékai alapján értékelte az intézmények munkáját, és megpróbálta a kutatási eredmények alapján eredményességüket növelni. A bizonyítékon alapuló közpolitika-alkotás sok helyen egyértelmű modernizációs törekvésekkel fonódik össze. ${ }^{2}$

A tényeken alapuló oktatáspolitika iránti igény a hazai közoktatás-politikai diskurzusnak is bevett részévé vált az elmúlt évtizedek során (Halász, 2009). A módszer megfogalmazói nemcsak a tervezéssel állítják szembe a müködőképességet, hanem az ideológián alapuló közpolitika-formálással a tudáson alapuló közpolitika-alkotást is, azaz a tudáson alapuló közpolitika-alkotást implicite ideológiamentesnek tételezik fel.

A közpolitika szociológiájával foglalkozó szakirodalomban számos példát találunk azonban arra, hogy a tudás és a számok nem minden esetben jelentik egyben az objektivitás biztosítékát is. Gauthier és Gouvello (2010) a francia közoktatás-politika tanulmányozása során például arra a következtetésre jutott, hogy a francia oktatási kormányzat számára, amely elsősorban a már rendelkezésre álló igen kiterjedt és nagy mennyiségü statisztikai adatot használta fel döntései megalapozásához a szerzők által vizsgált közpolitikai folyamatban, a statisztikák létrehozásának és felhasználásának elsődlegességét más tudásformákhoz képest nem az objektivitásukba vetett hit, hanem leginkább pusztán az magyarázza, hogy létrehozásuk egyszerü és relatíve gazdaságos. A számok mindenhatóságával kapcsolatban nem árt észben tartanunk azt sem, hogy a rendelkezésre álló felhalmozott tudást, amelynek egésze esetleg valóban akár pontos képet is adhatna egy-egy szakpolitikai területröl, a legtöbbször, akár ideológiai, akár pusztán praktikus okokból, valójában csak igen szelektíven használják fel.

A tudás létrehozását és felhasználását torzíthatják további tényezők is. Franciaországban például a már említett hatalmas mennyiségü adatot maga az állam gyártja. Emiatt az állami szereplők igénye kifejezetten alacsony arra, hogy a bőségesen rendelkezésre álló adatok mellett további, nem állami forrásból származó tudásokat, kutatási eredményeket keressenek és vegyenek figyelembe. Ilyen esetekben a tudás könnyen válik túlegyszerüsítetté, a tudástermelés pedig könnyen válhat pragmatikus megfontolások által befolyásolttá (Gauthier és Gouvello, 2010, 64-66. o.).

A rendelkezésre álló statisztikák felhasználása társadalmanként különbözhet sok egyéb tekintetben is: miközben a legtöbb társadalomban az adatok, statisztikák formájában rendelkezésre álló tudás egyik fő célja az átláthatóság és az elszámoltathatóság, és ezért ezek teljesen nyilvános adatok, más esetekben, például a már többször idézett Belgium esetében, ahol a „diszkréció logikája” a társadalom osztottságából következik, az adatok nyilvánosságra hozatala elé sok akadály gördül. Hasonlóan nem volt mindig evidens Magyarországon sem, hogy az Országos Kompetenciamérés adatai például nyilvánosságra kerülhetnek-e vagy sem. ${ }^{3}$

Ugyanakkor, ha az adatok nyilvánosak, akkor a belölük kinyerhetö tudás nemcsak a döntéshozókat informálja annak érdekében, hogy bölcs döntéseket tudjanak meghozni, 
hanem a döntésekben érintettek elé is tükröt tart: sokszor másokkal való összehasonlítás formájában, az érintettek által korábban figyelembe nem vett vagy fontosnak nem tartott kritériumok alapján informálja őket saját müködésükről, s ezáltal ösztönzi őket jövőbeni cselekvésekre.

Az ilyen eszközöket tudásalapú szabályozó eszközöknek nevezi a szakirodalom (Salamon, 2002), s fö funkciójuk, hogy egy bizonyos fajta, jól körülhatárolható tudást terjesszenek el annak érdekében, hogy az adott közpolitikai tér szereplöinek viselkedését befolyásolják. A tudás alapú szabályozó eszközök sok esetben számok formájában jelennek meg. A számok oktatáspolitikai jelentősége elsőként a nemzetközi térben mutatkozott meg, s ennek nyomán a ,kilencvenes évektől kezdve a rangsorolás és a különbözö összehasonlító adatsorok az oktatási szervezeteken belüli innovációk és változások fontos közpolitikai eszközeivé váltak" (Steiner és Khamsi, 2003, 2. o.). ${ }^{4}$

Vajon ezáltal létrejön-e a tényeken alapuló közpolitika-alkotást hirdető döntéshozók és tanácsadók által megálmodott, ideológiamentes (és pragmatikus) döntéshozatali folyamat? Aligha, elég, ha arra gondolunk, hogy mit mondanak a „tudás alapú társadalmak”, az „információs társadalom” szociológiai elméletei az adat, az információ és a tudás fogalmai közötti különbségekről, amikor is hangsúlyozzák ezek kontextusfüggőségét. Információ ugyanis éppen azért jöhet létre, mert valamilyen különbség hordozójaként jelenik meg egy adott rendszer egyéb elemeihez képest, s a rendszer szabályainak megfelelő módon van kódolva. Ezek szerint az elgondolások szerint az információ, s az ezen alapuló tudás tehát rendszer-függö, csak az adott rendszeren (pl. az orvostudományon) belül lehet értelmezni, s nem jöhet létre a különböző rendszerek közötti, torzítások nélküli információcsere. Amint egy másik rendszerbe kerül át az információ, ott puszta adattá válik, amelyet ez a rendszer a saját szabályainak megfelelően kódol újra, s így válik új információvá (Nassehi és mtsai, 2007). Azaz, a fordítási folyamat során az információk, még ha „régi nevükön” is illetik őket, valójában megváltoznak: nem ugyanazt a jelentést hordozzák a különböző tudásterületeken belül. Ilyesmire az oktatás területén szemléletes példát nyújtanak a különböző pszichológiai eredetü elnevezések, amelyek azonban az oktatási közegbe átemelődve tanulási problémákká kódolódnak át. Legtöbbjük nem kizárólag iskolai, hanem orvosi kategóriaként jelenik meg a hétköznapi használat során, s úgy tünhet, mintha a terminológiát a gyógypedagógia, majd az általános iskola látszólag csak mintegy kölcsönvette volna azáltal, hogy alkalmazni kezdte (idetartoznak a fogyatékosságok, pszichiátriai zavarok, motoros diszfunkciók, s a részképességzavarok is). Nikolas Rose szerint ugyanakkor például maga a „fejlődés”, illetve a „normális fejlettségi szint” pszichológiai fogalmai is sokat köszönhetnek az iskolának mint olyan intézménynek, amelyben lehetségessé vált egyszerre sok hasonló korú gyermek vizsgálata, s eredményeik egymáshoz képesti elemzése. Hiszen az, hogy mi tekinthető normálisnak, s mi az ettől való eltérésnek, csak bizonyos esetszámon felül, megfelelő számú ,átlagos” eset jelenlétében világlik ki, s csak így válnak a gyakorlatban is alkalmazhatóvá, s statisztikailag értelmezhetővé a rendellenességek leírására szolgáló kategóriák (Rose, 1996).

Mindez ismét csak óvatosságra kell, hogy intsen azokkal az elképzelésekkel kapcsolatban, amelyek a tudás és a számok mindenhatóságát, de-ideologizálhatóságát hangsúlyozzák.

A számok objektivitásába vetett hittel kapcsolatban szintén érdemes Nikolas Rose-t idéznünk. Rose arra figyelmeztet, hogy az objektivitás látszatát hordozó számok valójában éppoly értékterheltek lehetnek, mint bármely, más alapokon nyugvó közpolitika-alkotás: „a számok teszik lehetővé és ellenőrizhetővé a kormányzás modern formáit [...]. Nemcsak a számok tünnek egyre nélkülözhetetlenebbnek a politika és a kormányzás számára, de egyben újrarajzolják a politika és az objektivitás közötti határvonalat is, amennyiben az ítéletek meghozását, a prioritások kijelölését és a források elosztását 
automatikusan meghatározó technikai mechanizmusokként tünnek fel" (Rose, 1999, 198-199. o.)..$^{5}$

A ,politikus számok” (Rose i. m.) avagy a „számok általi kormányzás” (Grek és Ozga, 2008) felé történt elmozdulás legszembetünőbb példája az OECD PISA-vizsgálata, amely egyszerüen megfogalmazott üzeneteivel és könnyen kommunikálható eredményeivel tett már-már egyeduralomra szert a nemzetközi, és számos nemzeti oktatáspolitikai diskurzus-térben.

De nemcsak adatbázisokon és számokon keresztül tud a tudás érdemben befolyásolni egy-egy közpolitikai területet. Erre példa a 2000-es évek elején Skóciában létrejött „,integrált gyermekügyi szolgáltatások" megszületése, amelynek egyik fontos lépéseként a létrejövő integrált tudás felülírta a hagyományos, gyermekekkel kapcsolatos (pl. közoktatásra, szociális, egészségügyi szektorra tagolódó) tudások struktúráját, s ekképpen a létrejövő ,új tudás” alapvető hatással van a közpolitikai gyakorlatra is: az elszámoltathatóságot központba állító új közpolitikai elképzelés tulajdonképpen az új tudás megjelenésének és terjedésének köszönhetően tud a gyakorlatban megvalósulni a kutatási beszámolók szerint (Grek és mtsai, 2009, 16-17. o.).

A tudás- és ismeretszerzési akaratnak az intézményrendszer, a különböző aktorok egyszerre lehetnek tárgyai és alanyai is. Az oktatás esetében a mérés-értékelési rendszerekben az iskolák, a tanárok, diákok a központi oktatásirányítás számára leginkább az összehasonlítás, a rangsorállítás tárgyai. Ugyanakkor a mérési eredmények értékelését, azok továbbgondolását nem pusztán az oktatásirányítás végzi, hanem maguk a mérések tárgyai is egyre inkább foglalkoznak ezekkel: saját eredményük megismerése fontos részévé válik a tevékenységüknek. Ily módon akképpen válnak ellenőrizhetővé és kormányozhatóvá, hogy nincs szükség közvetlen megfigyelésükre és szabályozásukra, a tudás egy olyan fontos közvetett irányítási eszközzé válik, amellyel mindez kiváltható; saját magukat szabályozzák.

A már többször idézett Ball szerint az oktatásban egyre inkább teret nyerő, az eredetileg az iparból kölcsönzött minőségbiztosítási technikák is építenek arra, hogy különleges „mikro-fegyelmezési praktikáikkal” és „távolról való igazgatással” érjék el az adott intézményrendszerben tevékenykedőknél, hogy a közpolitikai kívánalmaknak megfelelően viselkedjenek. Ily módon az igazgatás többé már nem ,,a szabályok és folyamatok engedélyezésére és betartatására" vonatkozik, hanem jóval inkább arra tesz kísérletet, hogy „meghatározza, hogyan gondolkozzanak az alkalmazottak, és hogyan érezzenek saját munkájuk iránt... az indikátorok befolyásolják azt a jelenséget, amiről jelzést adnak"6 (Ball, 2006, 522. o.).

A számok, a bizonyítékok a nyílt diktatúrákon kívül minden tömegtársadalomban egyre fontosabb szerepet töltenek be nemcsak a közpolitika-alkotásban, de a nyilvános politikai érvelésekben is. Persze ez a szerep sokszor pusztán legitimációs alapként szolgál. Az ezzel kapcsolatos ellentmondásos helyzetet a legjobban talán az olyan politikai kommunikatív aktusokban lehet tetten érni, mint a jelenlegi magyar kormány által több ízben is bevetett „Nemzeti Konzultációra” keresztelt reklámkampány, amely, piaci cégek marketingfogását követve, látszólag „tudományosan” megalapozottan kérdezi meg az emberek véleményét bizonyos dolgokról. S miközben a konzultáció legitimációját éppen a konkrét kérdéskörre érkező nagyszámú válaszra igyekeznek alapozni, pontosan az ezt elméletileg lehetővé tevő „tudományosság” alapvetéseire hánynak fittyet, amikor nem felelnek meg a legalapvetőbb statisztikai-módszertani elvárásoknak, vonatkozzanak azok akár az eredeti minta, azaz a teljes lakosság és a tényleges válaszadók közötti kapcsolatra, akár a feltehető kérdések formájára és típusára, akár a beérkezett válaszokból levonható következtetésekre. 


\section{Kontextus, aktorok, színterek}

A közpolitikák szociológiai elemzése evidens módon hangsúlyozza, hogy a társadalmi kontextus nagymértékben befolyásolja, hogyan tud megvalósulni egy-egy elképzelés. Kontextuson itt olyan, alapvető adottságokat vagy szokásokat kell érteni, mint például azt, hogy egy társadalomban az általános politikai viselkedésre vonatkozó szabályok a konszenzusra való törekvésre, versengésre vagy konfliktusokra ösztönöznek-e inkább (Schmidt és Radaelli, 2004; Delvaux és Mangez, 2008, 113. o.). A formális, informális struktúrák, törvények ugyancsak erős hatással vannak az aktorok közös vonatkoztatási keretére és látásmódjára. Erre az egyik legszemléletesebb példa Európában a belga „konszociatív demokrácia” (Lijphart, 1977), ahol az egymástól élesen elkülönülő társadalmi „,pillérek” közötti együttélési kényszer miatt a kompromisszumkeresés meghatározó eleme a közpolitika-alkotási folyamatoknak.

Nemcsak az adott társadalmi berendezkedés van hatással a közpolitika-alkotási folyamatokra és azok korlátaira, hanem bizonyos tekintetben útfüggőség is jellemzi a legtöbb társadalmat - a történelmi tapasztalatok, a múltbeli gyakorlatok és döntések ,alakítják és kijelölik azt, amit megcsinálhatónak gondolunk a jelenben" (Delvaux és Mangez, 2008, 111. o.).

A közpolitika történelmi meghatározottságát jól példázza a portugál közoktatásban az iskolavezetés szabályozásának története. A tanárok és a szakszervezetek számára ennek az ügynek szimbolikus jelentősége volt, és kapcsolódott a Salazar utáni demokratizálódási folyamathoz: az 1974-es forradalmat követő egyik első oktatási minisztériumi rendelet a tanárok által demokratikusan választott vezetőségekkel váltotta fel a régi rendszer által kinevezett iskolaigazgatókat. A rendelet (és a gyakorlat) azóta számos ponton, alapjaiban változott meg, ugyanakkor az esemény szimbolikussága miatt a mai napig utalást tartalmaz a „demokratikus igazgatás” koncepciójára (Barroso és Menitra, 2009).

Az uralkodó politikai diskurzus típusa is befolyásolja, hogyan zajlanak a közpolitikai folyamatok. Schmidt és Radaelli (Schmidt és Radaelli, 2004, 196-197. o.) szerint alapvetően kétféle politikai diskurzus különböztethető meg. A koordinatív politikai diskurzus a közpolitika alkotók és egyéb aktorok közötti alkufolyamatot jelenti, míg a kommunikatív diskurzus a szélesebb közönség meggyőzésére irányuló diskurzus. A kétféle diskurzus természetesen nem zárja ki egymást, de a szerzők számos példát hoznak, amelyekkel amellett érvelnek, hogy adott kormányzási stílusok meghatározzák, hogy melyik válik az uralkodó típusú diskurzussá. Mint már említettem, Belgiumban, ahol az állam relatíve gyenge és a társadalmi pillérek (egyházi/világi), amelyek hiteken és értékválasztásokon alapulnak, autonómak, az oktatáspolitika-alkotási folyamat nagyjából az érintett felek közötti állandó tárgyalások és kompromisszumkötések sorozataként írható le. Ezzel ellentétben az angolszász országokban a nyilvános konzultációs folyamatoknak nagy szerepük van a közpolitika-alkotásban. Erre kiváló példa az Angliától függetlenedő skót kormány, amely müködését egy sor nyilvános konzultációval kezdte a legfontosabb közpolitikai kérdéseket illetően, beleértve az oktatást is. A konzultációs folyamatokban folytatott intenzív kommunikációs kampány a legszélesebb rétegeket célozta, s célja elsősorban az adott közpolitikában megjelenő új szemlélet (,,integrált gyermekügyi szolgáltatások") megismertetése és elfogadtatása volt a társadalommal (Grek, Ozga és Lawn, 2009).

Nemcsak „belső” meghatározottságok, hanem „külső” hatások is érvényesülnek egy-egy közpolitika-alkotási térben. A nemzetközi színtéren megjelenő ötletek, közpolitikák különböző közvetítő szereplök (mediátorok, tudásbrókerek) által eljutnak a nemzeti oktatáspolitika területére, „kölcsönözhetővé” válnak. Ez szélesebbre tárja a rendelkezésre álló lehetőségek horizontját, ötletek egész tárházát kínálhatja fel. Az is gyakori azonban, hogy a kölcsönözhető fogalmak és ügyek hatása csak látszólagos a honi 
agendára, az előbbiek valójában inkább csak legitimálják az utóbbiakat, s a rendelkezésre álló lehetőségek közötti válogatás tendenciózusan zajlik: olyan közpolitikai eszközöket és módszereket kölcsönöznek, amelyek beleilleszthetők az aktuális elképzelések közé.

A kölcsönzés, a nemzetközi jó gyakorlatokra és példákra való hivatkozás gyakori, de nem probléma nélküli eleme a közpolitika-alkotási folyamatoknak. Elöfordul, hogy egy jó gyakorlat átültetése során nem veszik figyelembe a teljesen eltérő társadalmi kontextust két ország között, de ellenkező típusú problémákra is akadnak példák. A magyar közpolitika-alkotásban ilyen volt például, amikor, elsősorban az angolszász típusú oktatási rendszerekre hivatkozva, azok mintáját követve, létrejött a decentralizált oktatási rendszer. Politikai okokból a rendszerváltás időszakában (a felülről irányított államszocialista rendszerrel való teljes szakításra tett erőfeszítéseknek köszönhetően) azonban ezt nem kísérte semmiféle tanfelügyeleti vagy egyéb ellenőrzési rendszer átgondolt létrehozása, holott ez utóbbi legalább olyannyira fontos jellemzője volt az angol rendszernek, mint maga a decentralizáció.

A nemzetközi tér nemcsak közpolitikai eszközök és jó gyakorlatok kölcsönzése révén nyomhatja rá bélyegét egy ország közpolitika alkotási folyamatára. A különböző nemzetközi vagy nemzetek feletti szervek saját közpolitikai irányvonalakat képviselnek, amelyeket direktebb vagy indirektebb eszközökkel igyekeznek érvényesíteni a különböző nemzeti közpolitikai terekben. A magyar közoktatás-politikai térre az elmúlt tíz-húsz évben ilyen nemzetközi hatásként jelenik meg az EU, nem is annyira az oktatási irányelvek, mint inkább a fejlesztési pénzek szétosztása miatt; ugyancsak jelentős hatást gyakorolt az OECD által létrehozott PISA-vizsgálat is a magyar közpolitika-alkotási térre. A nemzetek feletti szervek által nyújtott oktatási víziók, de a finanszírozási módok, finanszírozási struktúrák átalakulása is erősen befolyásolhatja tehát a nemzeti szintet. Különösen igaz ez Magyarországra, ahol fejlesztési források híján már az EU-csatlakozás előtt jellemző volt, hogy a különböző oktatási fejlesztések nemzetközi pénzekből valósultak meg (PHARE-programok). Ez a tendencia a 2004-es EU-csatlakozással erösödött. Ez nemcsak azt jelenti, hogy az EU-s fejlesztési irányelvek helyi értelmezése teremti meg annak a lehetőségét, hogy a magyar közoktatásban bármiféle fejlesztés végbemehessen, hanem azt is, hogy létrejöttek új, az oktatás szektorán kívül eső intézmények, elsősorban a Nemzeti Fejlesztési Ügynökség, és az EU-s források tervezésével megbízott más szereplők, amelyek befolyásos aktoraivá váltak az oktatástervezésnek, közpolitika-alkotásnak.

A politikai szociológia figyelmeztet rá, hogy a közpolitikai folyamatokban részt vevő aktorok száma nem korlátozódik a központi szabályozásban szerepet vállaló bürokratákra. Potenciálisan fontos aktorok lehetnek nemcsak parlamenti képviselők vagy helyi politikusok, hanem igen fontos szerepet töltenek be például a szakértők vagy tanácsadók, akiknek tudása akár közvetetten, akár közvetlenül, de megjelenhet a közpolitikai döntéshozásban.

A közpolitika szociológiai megközelítései azonban ennél jóval tovább merészkednek, és azt állítják, hogy a közpolitikák végeredményben a gyakorlati értelmezés során nyerik el valódi tartalmukat, ezért elemzésük nem érhet véget a kormányzati döntéshozatallal - a közpolitika valós következményei, eredményei és funkciói ugyanis csak a gyakorlatban, a hétköznapokban tárulnak fel. Majone és Wildavsky (idézi: Freeman, 2009, 431. o.) szerint egyenesen arról van szó, hogy ,amikor implementálunk egy közpolitikát, egyben meg is változtatjuk azt; az implementáció szükségképpen újraartikulálja a közpolitikát. A szó szerinti implementáció - szó szerint lehetetlen."7 A kiinduló közpolitikai szándék ugyanis a különböző színterek és aktorok kölcsönhatásának nyomán alakul, s ennek a hosszas iteratív folyamatnak az eredményeképpen jön létre a szabályozás, s a helyi szintü alkalmazás; végeredményben pedig ezt tekinthetjük a közpolitika gyakorlatának. A közcselekvési megközelítésböl szervesen következik, hogy a helyi szereplők jelentősége mellett nem mehetünk el szó nélkül. Ezek a helyi szereplők maguk is 
tevékeny aktorok, csakúgy, mint a közcselekvés „kitalálói”, hiszen tulajdonképpen ők valósítják meg a közpolitikát, ők ültetik azt át a gyakorlatba. A megvalósítás során értelmezik, jelentést tulajdonítanak a közpolitikai elképzelésnek, „lefordítják”, a saját helyi viszonyaikhoz igazítják azt.

A közpolitikai gyakorlat kiemelten fontos szereplői az „utcaszintü bürokraták” (Lips$k y, 1980)$, azaz, a közpolitikát ténylegesen a gyakorlatba átültető állami alkalmazottak, mint például a tanárok vagy a szociális munkások. Az aktoroknak ez a csoportja az, amely a szabályozást értelmezve és alkalmazva, rendszeresen találkozik a közpolitikai célcsoportokkal, s a közcselekvés ezekben a hétköznapi találkozásokban, például a tantermi értelmezési munka során (Ball, 1997) teljesedik ki. Ebben a megközelítésben az iskolai (vagy éppen a kórházi) valóság olyan diszkurzív kontextusként elemezhető, ahol a közpolitika nap mint nap megtörténik, és új értelmet nyer (Bowe és mtsai, 1992, 23. o.).

A politikai döntéshozatalnak van egy további szereplöi köre, noha nem rendelkeznek a szakértői pozícióhoz hagyományosan szükséges tudományos háttérrel, mégis fontos szereplöivé válhatnak a közpolitikai folyamatoknak. Ezek az új résztvevők sokszor a közpolitika tényleges érintettjei: a betegek, tanulók, szülők, felhasználók, általában a szakpolitikai „célcsoportok”. A felhasználók bevonhatók a közpolitikai folyamatba, ekkor hozzáadott értékük nem a szakértők hagyományosan vélelmezett objektivitásában, hanem éppen ellenkezőleg, szubjektivitásukban rejlik. Nem kívülröl és felülröl, hanem belülről ismerik azokat a problémákat, amelyekröl beszélnek. Személyes tapasztalataikkal hozzájárulhatnak a döntések legitimitásához, és életszerübbé képesek tenni azokat. Ugyanakkor, sokszor, még ha nem vonják is be öket a döntési folyamatokba, még ha azok a „fejük felett” születnek is meg, a terepen ők maguk is részeseivé válnak a közpolitikai folyamatnak, s re-, de akár proaktív viselkedésükkel (amire a legszemléletesebb példa a szabad iskolaválasztás) alapvetően hozzájárulhatnak a közpolitikai folyamat megvalósulásához.

A közpolitika egyszerre több különböző színtéren (szcénán) alakulhat. Ezen színterek némelyike része a hagyományos bürokratikus szervezeteknek, de jelentős részük egészen más formában jött létre.

Új szereplők bevonása sokszor új típusú politikai színterek megjelenésével (pl. deliberatív jellegü konzultációk megszervezése; új típusú érdekvédelmi/kamarai jellegü testületek életre hívása) lehetséges, amelyek intézményes formában teszik lehetővé az együttmüködést viszonylag nagyszámú „társadalmi partnerrel”. Ellentétben a modern demokráciák egyes alapintézményeivel (pl. parlament), amelyek felállítása és múködésmódja tekintetében igen sok elöírás, alkotmányos kötöttség érvényesül, a szóban forgó intézmények létrejötte és működése általában kevésbé szigorúan szabályozott. Ez azzal a következménnyel is jár, hogy egyes szereplök, föként a végrehajtó hatalom birtokosai jelentős szabadsággal rendelkeznek a tekintetben, hogy milyen összetételü, müködésmódú grémiumokat hoznak létre, illetve milyen jogosítványokkal, erőforrásokkal látják el ezeket.

\section{A közpolitika mint szöveg: diskurzusok, narratívák, gyakorlatok}

Amennyiben a közpolitikákat társadalmi jelentésük szempontjából elemezzük, a szövegeknek központi jelentőséget kell tulajdonítanunk: a közpolitikáknak mint szövegeknek s a közpolitikákkal kapcsolatosan kialakuló szövegeknek egyaránt.

A diszkurzív elemzés ennél tovább is megy: nemcsak szövegként tekint a közpolitikára, hanem egy olyan csatatérként is, amelyben a nyelvet - avagy, még pontosabban, a diskurzust - taktikusan használják (Fulcher, 1989, 7. o.). Ez a megközelítés rokon azzal a már említett meglátással, amely szerint a közpolitikák alapvetően a jelentésekért foly- 
tatott küzdelem során formálódnak. Ugyanakkor a diszkurzív megközelítés azt is hangsúlyozza, hogy a szövegeknek nem pusztán egyetlen olvasatuk létezik. Codd szerint ,a közpolitika-elemzés igazi feladata talán az, hogy megvizsgálja azokat a különböző hatásokat, amelyeket a dokumentumok az olvasókban létrejövő jelentésekre gyakorolnak" (Codd, 1987, 239. o.). A diskurzussal foglalkozó kutatók elképzelései sokszor Michel Foucault gondolatainak továbbgondolásai, alkalmazásai a közpolitikai térben.

Foucault-t elsősorban a hatalom kérdései izgatják, s a diskurzust is ezért tartja fontosnak. Szerinte ugyanis a diskurzusok elemzésének azért van kiemelt szerepe a történettudományban és a társadalmi változások értelmezésében, mert a diskurzusok kimondatlan, ámde nagyon is erős szabályai (,,a diskurzus rendje”) határozzák meg, hogy milyen társadalmi jelenségek hogyan és miként tudnak létrejönni, milyen jelentésekkel ruházódnak fel alakulásuk során. A diskurzus egyrészt közvetíti a hatalmi elvárásokat, ugyanakkor azáltal, hogy kijelöli a lehetséges és a nem lehetséges tartalmakat, a hatalom létrehozója is egyben: „... a diskurzus nemcsak egyszerüen tolmácsolja a küzdelmeket és az uralmi rendszereket, hanem érte folyik a harc, érte dúl a küzdelem; tehát a diskurzus az a hatalom, amelyet az emberek igyekeznek megkaparintani" (Foucault, 1991, 869-870. o.) Foucault diskurzuselmélete olyan értelemben ugyanakkor nem kritikai, hogy rámutat: tudás és hatalom, diskurzus és hatalom fenti kapcsolata nem küszöbölhető ki: „.... diskurzus előtt nincs prediszkurzív viselkedés... [...] A diskurzust olyan erőszakként kell felfognunk, amit a dolgokon követünk el, mint valami általunk a dolgokra erőszakolt gyakorlatot, és a diskurzus eseményei e gyakorlatban találják meg szabályszerüségük elvét" (Foucault, 1991, 879. o.).

A diskurzusok, s különösképpen a diskurzusban végbemenő hangsúlyváltások elemzését azért is tartom kiemelten fontosnak a közpolitikák szociológiai elemzése során, mert hipotézisem szerint ezek a váltások sokszor egyben politikai programok és kormányzási eszközök váltását is jelzik, illetve magyarázzák. A diskurzus hangsúlyváltásainak egyértelmüen van időbeli dimenziója, de félrevezető lenne, ha éles cezúrák által megkülönböztethető, időben egymást követő szakaszok határoló elemeiként fognánk fel őket. Egy diskurzus különböző elemei - mint az oktatási diskurzusban a továbbiakban tárgyalandó autonómia, a minőség, a bizonyítékok fogalmai - egyszerre lehetnek jelen a diskurzusban, azonban a diskurzus hangsúlyai változnak, s ennek megfelelöen hol egyik, hol másik elem kerül előtérbe.

Ráadásul a diskurzus változásai sosem varázsütésszerüen mennek végbe. Ez már csak azért is evidens, mert a közpolitika-alkotás egyszerre sok szintéren zajlik, sokféle szereplö alakítja, akikre többféle elem hathat a nemzetközi diskurzusból is; $\mathrm{s}$ a változások nem egyszerre jelennek meg mindenhol. Az időbeli szakaszolás ezért föképp heurisztikus értékủ lehet, azt azonban jól érzékelteti, amikor a sok szakaszon átívelve az apró hangsúlyváltások nagyobb léptékủ változássá állnak össze. Az uralkodó diskurzus alapvető tulajdonságai és a diskurzuson belül végbemenő változások tulajdonképpen csak bizonyos távolságból, az előzményeket és a következményeket egyszerre figyelembe véve világlanak ki.

A diszkurzív megközelítés a változásokat nem a hagyományos kronológia szerint megfigyelhető és egymás után folytatólagosan bekövetkező eseménysorokban keresi. Egy-egy jelenség vagy fogalom kialakulásának elemei az idő és a tér különböző dimenzióiban léteznek, de nem feltétlenül ragadhatók meg folytonos történetként. A foucault-i diskurzuselemzés oktatási és oktatáspolitikai relevanciáját elemezve Popkewitz és Brennan $(1998,15$. o.) a tömegoktatás kialakulásáról például azt írják, hogy az „19. századi találmány, amely a társadalmon belüli különféle, egymáshoz képest többé-kevésbé autonóm módon múködő jelenségek együttes hatásából emelkedett ki. Az osztálytermi tanítás módjaiban bekövetkezett változásokkal egy időben születtek meg az első tanárképző intézmények, a modern egyetemek, alakultak ki a társadalomtudományok és a pszicho- 
lógiai diszciplínája. Ezen jelenségek pedig éppen akkor zajlottak, amikor a tömegoktatás új intézményeinek igazgatására hivatott modern állam gyökerei is kialakultak. Ugyanebben az időben jelentek meg olyan elképzelések, amelyek a személyek »oktathatóságát « járták körül: a gyermekkor, az osztályterem és az iskolaigazgatás kérdései." ${ }^{\text {"8 }}$ Az ilyen, egymástól viszonylag függetlenül megjelenő jelenségek (mint a fent idézett esetben a pszichológia, a modern állam és a tanárképzés rendszere) egymásra hatva, egymással kölcsönhatásba kerülve járulhatnak hozzá új intézmények (modern tömegoktatás) és diszkurzív váltások születéséhez.

A politológia diszkurzív institucionalizmusnak nevezett irányzata Foucault nyomdokain haladva a diskurzust a politikai cselekvés fontos elemének tekinti. „A diskurzus képes lehet arra, hogy a technikai és tudományos érveléseket telehintse olyan, általában is jobban felfogható narratívákkal, amelyek passzolnak a szakértők esemény- és emblematikus eset-értelmezéseihez, de még a katasztrófa-forgatókönyvekhez is, amelyek aztán kényszerítő erejü történeteket generálnak az aktuális problémák okairól, valamint arról, hogy mit kell tenni azért, hogy helyrehozhassuk a dolgokat, illetve arról, hogy e történetek miképpen illeszkednek a társadalmat megalapozó értékekhez" (Schmidt, 2010, 47. o.). Azaz, Michel Foucault felfogásához hasonlóan, a diszkurzív institucionalizmus azt hangsúlyozza, hogy a diskurzus jelentősége abban rejlik, hogy kijelöli azt, mit lehetséges és mit nem lehetséges elképzelni, kimondani egy adott politikai térben.

Az oktatáspolitika fentiekhez hasonló szellemiségben fogant elemzésére a magyar oktatáspolitika-kutatás közelmúltjában is találhatunk példát: Lukács Péter 1994-ben megfogalmazott hipotézisében például arról ír, hogy „az oktatáspolitikai változások irányát egy-egy adott időszakban alapvetően befolyásolja, hogy van-e az adott időpontban valamifajta uralkodó eszme, paradigma, amely a politikák megfogalmazásakor az oktatásügy megváltoztatására irányuló kezdeményezések hivatkozási alapjait, a célok kijelölését orientálja, s a szereplők nyilvános mozgásterét megszabja” (Lukács, 1994, 14. o.).

Számomra az oktatáspolitikai elemzés egyik fő kérdése, hogy az adott közpolitikák milyen oktatáspolitikai narratívákból fakadnak, s mindezek az oktatáspolitikai narratívák miféle oktatáspolitikai diskurzusban jönnek létre, s hogyan építik tovább ezt a diskurzust. Kérdés az is, hogyan függ össze közpolitikai és politikai diskurzus, s hogy végső soron miként épülnek fel a diszkurzív térben a szakpolitikák, s hogyan hatnak ezek aztán vissza a diskurzusban megjelenő uralkodó narratívákra.

A barkácsolás mint értelmezési keret

A fentiekben szó esett a közpolitika-alkotási folyamatok színtereiröl, szereplőiről, az uralkodó diskurzus jelentőségéröl, a közpolitikai folyamat társadalmi és nemzetközi kontextusáról, és azokról az új típusú irányítási eszközökről és tudásmódokról, amelyek a közpolitika-elemző szakirodalom szerint egyre befolyásosabbá válnak a közpolitikaalkotási folyamatokban. Azt, hogy miként állnak össze a szereplök elképzelései közpolitikává, a közpolitikai barkácsolás fogalma segíthet modellezni.

A tudásalapú kormányzás igénye nem jelenti azt, hogy a korábbi közpolitika-alkotási gyakorlatokhoz képest racionalizáltabb tervezés készíti elő a közpolitikákat. A racionális tervezés helyett egy ettől teljesen eltérő értelmezési keret segíthet megérteni a különböző közpolitikák létrejöttét. A kultúratudományban használt barkácsolás (bricolage) fogalma vihet mindehhez közelebb. Lévi-Strauss (Lévi-Strauss, 1962) a barkácsoló szemléletét és helyzetét a mérnökével állítja szembe. A mérnöki/tudományos gondolkodást az elmélet, a terv vezérli, a barkácsolót azonban az, hogy milyen eszközök és alapanyagok állnak rendelkezésére. Ismereteit nem tágítja, a meglévők összerendezéséből kell levonnia következtetéseket, vagy további, új tudásokat alkotnia - azaz „barkácsolnia”.

Lévi-Strauss elképzelésének komoly utóélete van a politikatudományi, közpolitika-elemzői irodalomban. Freeman értelmezése szerint a barkácsoló a különbözö eszközöket és alapanyagokat „jártában-keltében” összegyüjti, gondosan megőrzi 
őket, hogy majd idővel felhasználja. Mindezek az eszközök és alapanyagok „,magukon viselik korábbi alkalmazásuk körülményeit, de nem egyértelmüen behatárolható további használatuk köre és módja, nincsenek teljeskörüen értelmezve, manipulálhatók és felhasználhatók a legkülönbözőbb célokra. Nemcsak az eszközök beválogatásának módjában játszik fontos szerepet a barkácsoló célja, hanem magát a célt is alakíthatják a rendelkezésre álló eszközök és alapanyagok" (Freeman, 2007, 486. o.). ${ }^{9}$ Freeman figyelmeztet: mindez nem jelenti azt, hogy a barkácsolás „tudománytalan” lenne; s valóban, a tudományszociológiai kutatások éppen azt mutatják be, hogy a tudósok is így dolgoznak.

Freeman kutatásaiból azt szürte le, hogy a közpolitikai döntéshozás szükségszerüen barkácsolás révén megvalósuló tanulási folyamat, amely akkor vezethet eredményre (akkor valósulhat meg egy-egy új közpolitikai elem), ha a döntéshozó a közpolitika-csinálás során a különböző tudásokat nem csak az aktorok és az érdekek között, hanem az aktorok és érdekek által hordozott különböző gondolkodásmódok között is képes egyeztetni. Freeman szerint ez az egyeztetési képesség minden közpolitika-formáló szereplö számára nélkülözhetetlen (Freeman, 2007); ellenkező esetben ugyanis az „íróasztal mögött" kigondolt elképzelések nem válnak a gyakorlatban is müködő közpolitikává. Az egyeztetés, a tanulási folyamaton keresztül való érlelődés és csiszolódás funkciója tulajdonképpen az, hogy egy olyan platformot hozzon létre, amely a különböző hátterü gondolati világokat és különböző célokat képviselő érdekeltek számára hasonló jelentéssel bír. Ellenkező esetben elkerülhetetlenek a nyílt konfliktusok, csakúgy, mint egyszerüen az, hogy a közpolitika különböző elemei egészen más jelentéssel ruházódnak fel, mint amit eredetileg a döntéshozók szántak nekik, s ehhez az eredeti szándékhoz képest diszfunkcionálisan kezdenek „működni”. Azaz, amennyiben a közpolitika-alkotást idealizált közcselekvésként képzeljük el, akkor a barkácsolás szükségszerü velejárója a müködöképes közpolitika-csinálásnak.

Ball szerint ,„a nemzeti közpolitika-csinálás mindenképpen barkácsolási folyamat: ötlet-darabok kölcsönzése és másolása, lokálisan kipróbált megközelítések kiegészítése és felhasználása, elméletek, kutatások, irányzatok és divatok önkényes felhasználása, a szereplők gyakorta bármire lecsapnak, amiről első látásra úgy tünik, hogy müködik" (Ball, 1998, 126. о.).

Hozzátehetnénk, hogy a közpolitika-alkotásban a nemzeti oktatáspolitikák növekvő nemzetközi beágyazottsága nyomán egyre lényegesebbé válik a barkácsolás, hiszen az oktatáspolitika globalizálódásával mind gyakoribb a közpolitikai kölcsönzés (Steiner és Khamsi, 2004), illetve a nemzetközi jó gyakorlatokra való hivatkozás nemzeti szinten is. A külföldtől ellesett minták meghonosítói szükségképpen olyan fogalmakkal élnek, amelyek jelentése kontextusról kontextusra változik, azaz az egyik nemzeti oktatáspolitikai környezetből a másikba emelve, vagy éppen a nemzetek feletti kontextusból nemzeti keretbe beemelve a gyakorlatok mást eredményezhetnek, mint az eredeti környezetükben. A hazai környezethez igazítás, a meglévő gyakorlatokkal való egyeztetés, a különböző elemek egymáshoz csiszolása szükségszerü feladat.

A fenti sokrétüség miatt nem csupán azt állíthatjuk, hogy a közpolitikai szabályok interakcióban jönnek létre, de azt is, hogy önmagukban nem is értelmezhetőek, hiszen csak a gyakorlati értelmezés során nyerik el valós tartalmukat, amelyek a különböző alkalmazási közegekben különbözőek lehetnek. Ebben az értelemben a szabályok funkciója az, hogy alapot adjanak a helyi gyakorlatokhoz. A valóságban a szabályalkotás ugyanakkor sokszor legalább annyiszor meglévő gyakorlatok szabályokba foglalása, mint leendő cselekvések elöírása. 


\section{Jegyzetek}

${ }^{1}$ A jelen fejezet egyes részei korábban a Tudás és politika (Berényi, Erőss és Neumann, 2013) címü kötet elöszavaként jelentek meg tömörebb formában.

${ }^{2}$ Ennek egyik legjobb példája a Blair-kormány 1999-es kiáltványa az Egyesült Királyságban, amely a hangzatos, „A kormányzás modernizálása” (Modernising Government, 1999) nevet kapta.

${ }^{3}$ Az Országos Kompetenciamérésről lásd bővebben: Berényi, 2013.

\author{
${ }^{4}$ Saját fordítás. \\ ${ }^{5}$ Saját fordítás. \\ ${ }^{6}$ Kiemelés tőlem, B. E. \\ ${ }^{7}$ Saját fordítás. \\ ${ }^{8}$ Saját fordítás. \\ ${ }^{9}$ Saját fordítás
}

\section{Felhasznált szakirodalom}

Apple, M. (1996): Power, meaning and identity: critical sociology of education in the United States. British Journal of Sociology of Education, 17. sz. 125-144. DOI: $10.1080 / 0142569960170201$

Ball, S. (1997): Policy Sociology and Critical Social Research: a personal review of recent education policy and policy research. British Education Research Journal, 23. sz. 257-274.

DOI: $10.1080 / 0141192970230302$

Ball, S. (1998): Big Policies/Small World: An Introduction to International Perspectives in Education Policy. Comparative Education, 2. sz. 119-130. DOI: 10.1080/03050069828225

Ball, S. (2006): Education Policy and Social Class. World Library of Educationalists.

Barroso, J-Menitra, C (2009): Knowledge and Public Action- School Autonomy and Management. Kutatási Jelentés. Letölthető: http://www.scribd.com/ doc/53191030/joao-barroso-e-menitra-2009-knowledge-and-public-action-school-autonomy-and-management-1986-to-2009 Utolsó letöltés: 2014. március 7.

Béland, D. (2009): Sociology and Public Policy, ASA Footnotes, April, Issue, 37. Issue 4.

Berényi E. (2013): Az autonómia kormányzása. A magyar közoktatás-politika hangsúlyváltásai és az Országos Kompetenciamérés. In: Berényi E., Erőss G. és Neumann E. (szerk.): Tudás és politika. L'Harmattan, Budapest. 267-299.

Berényi E., Erőss G. és Neumann E. (szerk., 2013): Tudás és politika, L'Harmattan, Budapest.

Bowe, R., Ball, S. és Gold, A. (1992): Reforming Education and Changing Schools: Case Studies in Policy Sociology. Routledge.

Burawoy, M. (2006): Közérdekű szociológiát! Replika, 54-55. sz. 35-66.

Codd, J. (1988): The construction and deconstruction of educational policy documents. Journal of Education Policy, 3. 3. sz. 235-247.

DOI: $10.1080 / 0268093880030303$
Comaille, J. (2004): Sociologie de l'action publique. In: Boussaguet, L. és mtsai: Dictionnaire des politiques publiques. Presse de Science Po, Paris. 413-421.

Davies, H. T. O., Nutley, S. M. és Smith, P. C. (szerk., 2000): What works? Evidence-based policy and practice in public services. The Policy Press, Bristol. DOI: 10.1332/policypress/9781861341914.001.0001

Delvaux, B- Mangez, E (2008): Toward a sociology of knowledge and policy relation 1.1. The term 'public action': its contribution and ambiguities. KNOWandPOL kutatás, szakirodalmi összefoglaló, 2008. Internetes elérés (legutolsó letöltés: 2012. július): http:// www.knowandpol.eu/fileadmin/KaP/content/Scientific_reports/Literature_review/Literature_sythesis. Final_version.English.pdf

Dunn, W. (1981): Public Policy Analysis. Upper Saddler River, New Jersey.

Fulcher, G. (1989): Disabling Policies? A comparative approach to education policy and disability. The Falmer Press, London. DOI: 10.4324/9781315668253

Foucault, M. (1991): A diskurzus rendje. Holmi, 868-889.

Foucault, M. (1998): A kormányozhatóság. In: Michel Foucault: A fantasztikus könyvtár. Pallas Studió-Attraktor Kft., Budapest. 106-123.

Freeman, R. (2007): „Epistemological Bricolage: How Practitioners Make Sense of Learning". Administration \& Society, 39. sz. 476-496. DOI: $10.1177 / 0095399707301857$

Freeman, R. (2009) „What is “translation’?” Evidence and Policy, 5. sz. 429-447.

Gauthier, R.F - Gouvello, M (2010): Establishing "common core of knowledge and skills" at the end of compulsory education in France 2005-2006: "Politicisation" of the curricular arena and renewal of the knowledge base. Kutatási jelentés. Letölthető (2014. március 7.): http://knowandpol.eu/IMG/pdf/o21.franceducation.pdf

Gibbons, M. és mtsai (1994): The new production of knowledge: the dynamics of science and research in 
contemporary societies. Sage, London. DOI: $10.4135 / 9781446221853$

Grek, S. - Ozga, J. (2008): Governing by Numbers? Shaping Education through Data. CES briefing.

Grek, S., Lawn, B., Lingard, B., Ozga J., Rinne R., Segerholm, C. és Simon, H. (2009): National Policy Brokering and the Construction of the European Education Space. Comparative Education, 1. sz. 5-21. DOI: $10.1080 / 03050060802661378$

Habermas, J. (1994): Válságtendenciák a kései kapitalizmusban. In: uő: Válogatott tanulmányok. Atlantisz, Budapest.

Halász G. (2009): Tényekre alapozott oktatáspolitika és oktatásfejlesztés. In: Pusztai Gabriella - Rébay Magdolna (szerk.): Kié az oktatáskutatás. Tanulmányok Kozma Tamás 70. születésnapjára. Csokonai Könyvkiadó, Debrecen. 187-191.

Hood, Ch. (1991): A Public Management for All Seasons? Public Administration, 69. sz. 3-19. DOI: 10.1111/j.1467-9299.1991.tb00779.x

Kingdon, J. W. (1984): Agendas, Alternatives and Public Policies. Boston (Mass.): Little, Brown and Co.

Lévi-Strauss, Cl. (1962): La pensée sauvage. Plon, Párizs.

Lijphart, A. (1977): Democracy in Plural Societies: A Comparative Exploration. Yale University Press, New Haven.

Lipsky, M. (1980): Street-level Bureaucracy; Dilemmas of the Individual in Public Services. Russel-Sage.

Lukács P. (1994): Közoktatási paradigmák. Educatio, 1. sz. 14-26.

Maasen, S. és Weingart, P. (szerk., 2005) Democratization of Expertise? Exploring Novel Forms of Scientific Advice in Political Decision-Making. Sociology of the Sciences Yearbook, Vol. 24.

Maroy, Ch. (2007): The New Regulation Forms of Educational Systems in Europe: Towards a Post-bureaucratic Regime. In: Nils C. Soguel és Pierre Jaccard: Governance and Performance of Education Systems. Springer, 13-33. DOI: 10.1007/978-1-40206446-3 2

Marschall (1996): The autonomous chooser and ,reforms' in education. Studies in Philosophy and Education, 15. sz. 89-96. DOI: 10.1007/bf00367517

Muller, P. és Surel, Y. (1998): L'analyse des politiques publiques. Montchrestien, Paris.
Nassehi, Armin - Hagen-Demszky, Alma von der Mayr, Katharina (2007): The Structures of Knowledge and of Knowledge Production. Irodalmi összefoglaló, kutatási jelentés. Letölthető (2014. március 7.): http:// knowandpol.eu/IMG/pdf/lr.tr.nassehi_al.eng.pdf

Ozga, J. (1987): Studying educational policy through the lives of policy makers: an attempt to close the macromicro gap. In: S. Walker - L. Barton (eds) Changing Policies, Changing Teachers. Open University Press, Milton Keynes, UK. 138-150.

Popkewitz, Th. S. és Brennan, M. (szerk., 1998): Foucault's Challenge. Discourse, Knowledge, and Power in Education. Teachers College Press, Columbia University, New York.

Rose, N. (1996): Inventing our selves - psychology, power an personhood. Cambridge University Press.

Rose, N. (1999): Powers of Freedom. Reframing Political Thought. Cambridge University Press. DOI: 10.1017/cbo9780511488856

Rosen, L. (2009): Rhetoric and Symbolic Action in the Policy Process. In: Sykes és mtsai: Handbook of Educational Policy Research. Routledge. 267-285. DOI: $10.4324 / 9780203880968 . \operatorname{ch} 22$

Salamon, L. M. (szerk., 2002): The Tools of Governance. A Guide to the New Governance. Oxford University Press, Oxford.

Schmidt, V. A. (2010): Diszkurziv institucionalizmus. Az eszme és a diskurzus magyarázóereje. Századvég, 15. 57. sz. 35-78.

Schmidt, V. és Radaelli, Cl. (2004): Policy Change and Discourse in Europe: Conceptual and Methodological Issues. West European Politics, 27. 2. sz. March, $183-210 \quad$ (28). DOI: 10.1080/0140238042000214874

Steiner-Khamsi, G. (2003): „The Politics of League Tables". Journal of Social Science Education, (1). Internetes elérés: http:/www.jsse.org/2003/2003-1/ pdf/khamsi-tables-1-2003.pdf

Steiner-Khamsi, G. (szerk., 2004): The Global Politics of Educational Borrowing and Lending. Teachers College Press, New York.

Van Zanten, A. (2005): Bourdieu as education policy analyst and expert: a rich but ambiguous legacy. Journal of Education Policy, 20. 6. sz. 671-686. DOI: 10.1080/02680930500238887

Wagner, P. (1994): The Sociology of Modernity. Routledge, New York. 